\section{DAS RELAÇÕES ENTRE IDENTIFICAÇÃO E NOMEAÇÃO: O SUJEITO E O SIGNIFICANTE}

\section{Of the Relations between Identification and Nomination: The Subject and the Significant}

Las Relaciones entre la Identificación y Nombramiento : El
Sujeto y el Significativas

\begin{abstract}
Les Relations entre Identification et la Désignation : Le Sujet et le Signifiant
\end{abstract}

\begin{abstract}
Resumo
O presente artigo trata das relações entre o conceito psicanalítico de identificação e a noção de nomeação. Para tanto, inicialmente nos detemos na realização de um breve apanhado sobre os impasses e dificuldades presentes ao tratarmos do tema das identificações em psicanálise. Visitamos tanto alguns textos-chave de Freud quanto a leitura lacaniana, como forma de ampliar nossa discussão e procurar estabelecer uma articulação entre os autores, que não são trabalhados de forma distinta em nosso trabalho. Alguns conceitos e articulações tecidas por Lacan, tais como as identificações imaginárias e simbólicas, a questão do Nome-do-Pai e as discussões sobre o nome próprio são discutidas como forma de salientar a articulação entre identificação e nomeação. Posteriormente nos debruçamos sobre as operações de nomeação e renomeação propostas por Soler no texto Os nomes da identidade. Constatamos que as nomeações se configuram como operações de amarração, onde um determinado significante passa a fazer um tipo de ancoragem para o psiquismo. Vimos que em suas mais variadas formas as nomeações de algum modo marcam o sujeito, o inscrevem de uma determinada forma no simbólico. Da mesma forma que as identificações são constantes e sucessivas, se inscrevendo e reinscrevendo, também as operações de nomeação - em suas múltiplas facetas - se apresentam constantemente, não apenas na afirmação de um nome de batismo, mas em todos os momentos em que somos convocados socialmente a dar conta de algo, quando são interpelados pelo Outro e precisamos fazer frente a nosso desejo.
\end{abstract}

Palavras-chave: psicanálise; identificação; nomeação; sujeito; significante.

\section{Abstract}

The following article treats the relations between the psychoanalytic concept of identification and the notion of nomination. In order to do it, first we'll deter ourselves in realizing a brief résumé about the impasses and difficulties present as we deal with the theme of the identifications in psychoanalysis. We've visited some of Freud's key-texts and the lacanian literature as well, as means to amplify our discussion and look to establish an articulation between the authors, who aren't used on a distinct way in our work. Some concepts and articulations weave by Lacan, as the imaginary and symbolic identifications, the question of the Name-of-the-Father and the discussions about the proper name are discussed as means to point out the articulation between identification and nomination. Afterwards we lean over the operations of nomination and re-nomination proposed by Soler on the text The names of identity. We ascertain that the nominations are configured as operations of attachment, where a determined significant establishes a type of anchorage to the psychism. We've seen that in its various forms the nominations mark the subject in some way, inscribing them on a determined way on the symbolic. On the same way that identifications are constant and successive, inscribing and re-inscribing it selves, the nomination operations as well - on its multiple facets - present constantly, not only on the affirmation of a baptism name, but in all of the moments we're socially convoked to deal with something, when challenged by the Other and we need to face our desire.

Keywords: psychoanalysis; identification; nomination; subject; significant.
Artigo Original

\section{Leonardo Barros de Souza ${ }^{(1)}$ Leonardo José Barreira Danziato $^{(2)}$}

1) Psicólogo clínico, Mestre em psicologia pela UNIFOR, Membro da Invenção Freudiana - Transmissão da Psicanálise.

2) Psicanalista, Doutor em sociologia pela UFC, Professor do programa de Pós-Graduação em Psicologia da UNIFOR, Analista-membro da Invenção Freudiana - Transmissão da Psicanálise.

E-mail: leonardodanziato@unifor.br
Recebido em: 06/11/2013 Revisado em: 10/04/2014 Aceito em: 20/02/2014 


\section{Resumen}

El presente artículo trata de las relaciones entre el concepto psicoanalítico de identificación y la noción de nominación. Para tanto, inicialmente nos detenemos en la realización de un breve puñado sobre los impases y dificultades presentes al tratar del tema de las identificaciones en psicoanálisis. Visitamos tanto algunos textos-clave de Freud cuanto la lectura lacaniana, como forma de ampliar nuestra discusión y procurar establecer una articulación entre los autores, que no serán trabajados de una forma distinta en nuestro trabajo. Algunos conceptos y articulaciones tejidas por Lacan, tales como las identificaciones imaginarias y simbólicas, la cuestión del Nombre-del-Padre y las discusiones sobre el nombre proprio san discutidas como forma de relevar la articulación entre identificación y nominación. Posteriormente nos inclinamos sobre las operaciones de nominación y re nominación propuestas por Soler en el texto Os nomes da identidade. Comprobamos que las nominaciones si configuran como operaciones de amarradura, donde un determinado significante pasa a hacer un tipo de efecto de ancla para lo psiquismo. Venimos que en sus más variadas formas las nominaciones de algún modo señalan el sujeto, lo inscriben de una determinada forma en el simbólico. De la misma forma que las identificaciones san constantes e sucesivas, si inscribiendo y re inscribiendo, también las operaciones de nominación - in suyas múltiples facetas - si presentan constantemente, no apenas en la afirmación de un nombre de baptismo, mas en todos los momentos en que somos convocados socialmente a darse cuenta de algo, cuando interpelados por el Otro y necesitamos hacer frente a nuestro deseo.

Palabras clave: psicoanálisis; identificación; nominación; sujeto; significante.

\section{Résumé}

Le présent article traite des relations entre le concept psychanalytique d'identification et la notion de nomination. Pour cela, initialement nous faisons un brève apercu sur les impasses et difficulties inhérentes au thème des identifications en psychanalyse. Nous examinons aussi bien des textes-clés de Freud comme de la littérature lacanienne, afin d'approfondir notre discussion et établir un lien entre les auteurs qui ne sont pas étudiés de façon distincte dans notre travail.Certains concepts et articulations établis par Lacan, comme les identifications imaginaires et symboliques, la question du Patronyme et les discussions sur le nom propre sont traitées de façon à mettre en relief la relation entre identification et nomination.Ensuite nous nous penchons sur les opérations de nomination et re-nomination exposées par Soler dans son texte Les noms de l'identité.Nous constatons que les nominations se configurent comme opérations d'amarrage, où un déterminé significant passé á faire un type d'ancrage pour le psychisme.Nous montrons que dans ses formes les plus variées, les nominations marquent le sujet et l'inscrive dans une forme déterminée de symbolisme. De même que les identifications sont constantes et successives, s'écrivant et se réécrivant, l'opération de nomination - dans ses multiples facettes - se présente constamment pas seulement dans l'affirmation du nom de baptême, mais dans toutes les circonstances où nous sommes socialement invités à rendre des comptes, quand l'Autre nous interpelle et que nous avons besoin d'affronter notre désir.
Mots-clés: psychanalyse; identification; nomination; sujet; signifiant.

\section{Teorias da Identificação em Psicanálise}

Tratar da questão da identificação em psicanálise certamente não está entre as tarefas mais fáceis. Quem nos adverte sobre esta questão é Taillandier (1994):

Não há, em toda a teoria psicanalítica, domínio mais confuso, mais exasperante para o leitor do que o da teoria da identificação. Ao ler-se a incrível proliferação de termos supostamente técnicos que se vê aparecer nas publicações, tem-se a impressão de que a lista das identificações encontradas não se deterá nunca. (Taillandier, 1994, p.17)

Esta advertência, colocada pelo autor entre as primeiras linhas de seu texto, acentua as dificuldades que encontraremos neste percurso na mesma medida em que implica uma certa modéstia em nossas pretensões. Não seria possível elucidar a questão das identificações em Freud, que levaram Lacan a produzir uma série de desdobramentos posteriormente, de modo que iremos nos deter em traçar um caminho muito específico - eleito por nós dentre outros caminhos possíveis - buscando atingir nossos objetivos.

Pedimos a compreensão do leitor com relação a outro ponto, que julgamos merecedor de esclarecimento. Optaremos por não tratar nossa discussão sobre a noção de identificação de forma separada (identificação em Freud/ identificação em Lacan). Esta decisão se baseia no fato de que consideramos que a leitura de Freud, a partir de Lacan vai nos propiciar uma aproximação mais certeira em relação ao tema. Evidentemente que ao tratarmos de questões eminentemente lacanianas (como a questão do Nome-doPai por exemplo) estaremos dando prioridade ao texto de Lacan, mas nossa discussão sobre as identificações vai estar pautada numa articulação entre a leitura freudiana e a leitura lacaniana (onde alguns de seus comentadores também poderão nos ajudar).

\section{O que Podemos Dizer a Respeito das Identificações}

De início, gostaríamos de retomar o dizer de Freud (1921/1983c) a respeito da identificação: “A identificação é conhecida pela psicanálise como a mais remota expressão de um laço emocional com outra pessoa" (p.60). Esta colocação freudiana nos conduz a pensarmos na função de laço, enlaçamento, da identificação. A identificação em psicanálise, ao contrário da utilização corriqueira no senso 
comum, não é imitação, e nem um fenômeno em que um sujeito encontra algo seu no outro, algo com o que se identifica, e cria assim um vínculo com esse outro.

A identificação é da ordem do romance inconsciente do sujeito, um modo de pensar inconsciente que modifica o eu (Florence, 1994, p.118). A identificação neurótica aparece como um modo de criação, via desejo sexual, em que se encena um drama com situações, personagens, que afetam o eu. Uma identificação primária, originária, é condição para a instauração das identificações, para por em moção o desejo sexual, agente das identificações.

Em Totem e tabu Freud assevera que a primeira identificação (identificação primária) é aquela operada pela incorporação do pai, o pai primevo da horda, assassinado pelos filhos e posteriormente ingerido numa refeição totêmica (Freud, 1913/1983a, p. 61). O pai assimilado opera a primeira identificação, inscrição da lei simbólica, interdição do incesto. A identificação primária também tem uma estreita relação com a inscrição do significante Nome-do-Pai, como Lacan irá desenvolver mais tarde. Esta primeira identificação é possibilitadora do estabelecimento de vínculos do sujeito, do direcionamento da libido para outras fontes, objetos externos. Também é importante ressaltar, como coloca Florence (1994) que as identificações configuram a possibilidade de ligações afetivas diferentes do investimento erótico objetal (p.134).

A noção de identificação, portanto, está presente desde a própria constituição do sujeito, e daí em diante como modo de operação do desejo na tecitura de uma realidade inconsciente que se encena produzindo efeitos sobre o eu. Como coloca Cruglak (2001) a identificação primária dá início à série das identificações, é a matriz da série (p.23). Através das identificações o sujeito adiciona elementos a seu romance inconsciente, elementos vindos do outro, como salienta David-Ménard (1994):

...um sujeito, para se constituir, torna seus elementos vindos de outro, sendo que algo daquilo que o liga a esse outro permanece recalcado, mas de tal maneira que esses elementos, retirados do outro, dados pelo outro ou impostos pelo outro, implicam ao mesmo tempo de algum modo, falta para o sujeito. (David-Ménard, 1994, p.73)

Esses elementos, importados do outro, não são propriamente características. Os personagens do romance neurótico são representantes da representação inconsciente, são os significantes (Florence, 1994, p.122). É através das identificações que a cadeia significante se movimenta, promovendo a circulação dos significantes e a produção de novas significações pelo sujeito.

Em Psicologia das massas e análise do eu Freud produz um capítulo dedicado à questão da identificação. É nesse capítulo que são apresentadas, de modo mais sistemático, três fontes de identificações: a identificação primária, a identificação histérica e a identificação por contágio (Freud, 1921/1983). A primeira identificação, também chamada identificação originária, é a identificação ao ideal do pai, pai totêmico, discutida por nós acima. Gostaríamos apenas de enfatizar seu caráter primal, como a identificação que possibilita a instalação de todas as outras.

A segunda identificação, identificação histérica, se caracteriza pela apropriação de qualidades do ser amado (ou odiado), ou mesmo de seus sintomas (Freud, 1921/1983). Nessas identificações o sujeito recebe do objeto um único traço (Florence, 1994, p.131). Já a terceira identificação, chamada por Freud "identificação por contágio", onde Freud denota a ocorrência de uma espécie de "infecção mental". Aqui a identificação se dá ao nível do desejo: um ponto comum (inconsciente) emergente em uma determinada situação faz com que várias pessoas se "aglutinem" em torno deste ponto comum, que permanece inconsciente.

Retomando a questão do significante nas identificações nos parece pertinente discutir mais aprofundadamente a questão das identificações tomando os conceitos de simbólico e imaginário em Lacan. Tanto o processo de constituição do sujeito como os efeitos que o significante exerce em seu corpo ficam mais claros à luz dessa discussão proposta por Lacan, e esses pontos nos interessam bastante para podermos problematizar a função nomeante do significante e seus efeitos no corpo do sujeito.

\section{As Identificações Imaginária e Simbólica}

Ao retomar a questão das identificações depois de Freud, Lacan propõe o conceito de traço unário derivado do que Freud propõe em Psicologia das massas e análise do eu como Einziger Zug. Ao propor essa noção Lacan pretende sinalizar para o que há de radicalmente único no sujeito, o traço unário é pura diferença (Taillandier, 1994, p.20) marca o lugar singular do sujeito no campo da linguagem, é aquilo pelo qual cada um pode ser "um", suporte da marca da singularidade, a um só tempo é sinal de identidade e da própria diferença (Lacan, 2003, p.69).

Este conceito é de fundamental importância na teoria lacaniana das identificações, uma vez que para Lacan é o traço unário que leva a cabo as três identificações apontadas por Freud (Cruglak, 2001, p.22). Também é relevante lembrarmos o que salienta Safouan (2006) ao afirmar que antes de Lacan a questão da identificação tratava de saber sobre o outro a quem nos identificamos, e que com o trabalho de Lacan o enfoque vai se dedicar a tratar do que é ser "o mesmo" (p.143), discussão que vai levar a cabo pela via da diferença, do que é diferença por definição, o 
significante. Em seu intuito de investigar a questão do "mesmo" Lacan vai enveredar por caminhos diferentes dos de Freud, interrogando o processo de constituição do eu e a forma como o sujeito em constituição é inserido no campo da linguagem, conceituando as identificações propostas como imaginária e simbólica. Para tratarmos disto vamos primeiramente tomar suas ideias sobre o Estádio do espelho (Lacan, 1998).

Ao se interessar em elucidar a questão do narcisismo, tal como havia sido proposta por Freud, Lacan propõe uma teoria genética do eu, colocando a importância do outro na constituição do eu. Vai sustentar que o eu não é um estágio do desenvolvimento do ser humano, nem um advento de sua biologia. Lacan vai propor um esquema, referencial para a discussão que irá esboçar acerca da relação entre o eu e o outro, o estádio do espelho.

A importância do imaginário na constituição do sujeito está presente na obra de Lacan desde a proposição do estádio do espelho, que segundo Sales (2005) foi apresentado inicialmente por Lacan para tratar de sua discussão acerca do narcisismo primário. Tomando como referência diversos experimentos que vinham sendo realizados com a utilização de espelhos, tanto no campo da ótica quanto no da biologia, seu interesse é o de problematizar a relação do sujeito em constituição com a imagem refletida no espelho, uma relação marcada inicialmente por um fascínio pela imagem que aparece como imagem do outro e que terá efeitos gregários na constituição da imagem corporal do sujeito.

Segundo a autora o estádio do espelho inicialmente, em 1938, aparecia como um estágio do desenvolvimento infantil, representando um processo que vem em suplência à insuficiência orgânica do bebê prematuro. Já em 1949 o estádio do espelho passa a sua condição de estrutura permanente da subjetividade, uma relação marcada por uma certa pregnância paranoica do olhar do outro como algo que incide sobre o sujeito. O estádio do espelho ressalta a relevância da antecipação por parte do Outro materno, do olhar do Outro materno para que o eu possa se constituir como uma imago que representa um corpo, um corpo desenhado pelos traços do desejo do Outro. O estádio do espelho é uma teoria genética do eu (p.114), uma proposição de Lacan que rompe com uma concepção desenvolvimentista, na qual o eu se manifesta como um avanço da maturação da criança.

Vanier (2000) afirma que: "Ele [Lacan] faz do estádio do espelho um momento exemplar, paradigmático, de instauração da relação do homem com sua imagem e com seu semelhante" (p.37). O estádio do espelho atesta uma identificação, uma transformação que se produz a partir da assunção de uma imagem (Lacan, 1998), uma identificação imaginária que antecipa o advento do eu e a instauração de um corpo, um corpo unificado pela imagem especular que lhe confere um atributo de completude:

O estádio do espelho é um drama cujo impulso interno precipita-se da insuficiência à antecipação que, para o sujeito, preso na ilusão da insuficiência espacial, maquina os fantasmas que se sucedem de uma imagem de corpo fragmentado a uma forma que chamaremos ortopédica de sua totalidade e à armadura enfim assumida de uma identidade alienante que vai marcar com a sua estrutura rígida todo seu desenvolvimento mental. (Lacan, 1998, p.3)

Tal completude, no entanto se apresenta unicamente enquanto ficção, uma ficção do indivíduo, que fazendo função de antecipação da constituição do sujeito propriamente marca a relação de determinação que se estabelece com o âmbito social (Lacan, 1998 p.2). Como afirma Vanier (2005) o que decorre nesse momento é a instauração do narcisismo primário, a origem propriamente dita do eu (p.37). O que o estádio do espelho instala é a formação do corpo imaginário, unidade gregária que reveste o organismo, passagem da carne ao estatuto de corpo.

A constituição dessa imago, gestalt, tem poderes formativos, opera de forma gregária permitindo a formação de algo a que o bebê pode se identificar. Essa operação, uma identificação imaginária, apesar de seu caráter de engano salientado pela própria inversão da imagem no espelho dá consistência ao corpo fragmentado do bebê:

A saída para a angústia de despedaçamento é então a identificação com essa imagem especular cuja "gestalt" é responsável pela condução do processo de constituição do "eu"; saída que é, no entanto ilusória, pois vem alicerçada sobre um fundo inapelável de alienação. (Sales, 2005, p.116)

Lacan (1998) afirma que: "É por proteger desse momento de falta que uma imagem chega à condição de sustentar todo o valor do desejo: projeção, função do imaginário." (p.662). A identificação à falsa imagem do espelho constitui um momento necessário na formação do eu, um engano fortuito sem o qual a constituição do sujeito poderia estar irrevogavelmente prejudicada. O Imaginário tem uma relação estreita com essa noção de identidade, bem como com a assunção de uma imagem corporal que permite certa organização e fornece contornos à carne do bebê humano.

Sucessivamente a esta identificação tem início a série de identificações (Cruglak, 2001), que deverão agora ser marcadas pela sucessão e pela hiância do sujeito.

Como colocam D'Agord, Binkowski, \& Chittoni (2006):

...esta identificação (simbólica) já não é mais orientada 
pela unidade momentânea, mas por traços sucessivos, discurso. A substituição repetida de um traço primeiro é o processo de recalcamento que caracteriza a formação da metáfora paterna. (D’Agord et al., 2006, pp.119-120)

Cruglak (2001) propõe uma releitura da identificação por incorporação compreendendo que o termo assimilação e a metáfora da "refeição totêmica", incorporação da metáfora paterna, não implicam propriamente que algo é colocado para dentro do corpo, mas sim que a identificação primária incorpora algo que faz o corpo (p.32). O que é incorporado na identificação primária é um vazio, vazio constitutivo das bordas do corpo marcado pelo significante. Deste processo resulta um efeito, o efeito daquilo que Lacan apresenta sobre a cifra Nome-do-Pai, a função que permite o advento de nomear as coisas (p.34), balizador da entrada do sujeito na dimensão fálica que organiza sua economia pulsional.

Fazendo uma leitura a partir dos três registros da experiência humana apontados por Lacan em sua leitura de Freud é possível pensarmos nos aspectos imaginários e simbólicos das identificações. A exemplo da identificação à imagem pretensamente totalizante do espelho é imaginária toda identificação que busca uma identidade de completude, um fechamento de sentido. A identificação marcada no campo do imaginário fornece um ideal de identidade, aparece como uma identificação completa.

Já a identificação simbólica faz furo, falta, vem como suplência à totalidade enganosa do imaginário. Onde o imaginário busca um fechamento de sentido o simbólico aparece como abertura para a significação, onde a identificação imaginária pressupõe uma identidade permanente a identificação simbólica é marcada pela substituição sucessiva numa série de identificações (Cruglak, 2001). Não pretendemos sugerir uma polarização e completa distinção entre identificações imaginárias e simbólicas, uma vez que para Lacan os três registros representam dimensões da experiência indissociáveis. No entanto isso não impede que possamos explorar os diferentes aspectos de ambos, do mesmo modo que na teoria psicanalítica nos permitimos falar em Real, Simbólico e Imaginário de forma distinta.

Para pensar essa discussão entre identificação simbólica e imaginária e abrir nossa discussão acerca da questão do nome em psicanálise trazemos a distinção empregada por D’Agord et al. (2006) sobre as duas formas de identificação:

É imaginária a identificação que faz sentido para o sujeito, é simbólica a identificação que opera no sujeito. Ambas provêm do exterior, por isso dizemos que são oferecidas. Mas, se a primeira é aparentemente total como a imagem devolvida pelo espelho, a segunda será sempre falta, hiância, abertura para significância, no sentido de que um traço é repetidamente substituído, mas o que causa essa substitutibilidade é a vacância, a falta. Pois o sujeito não é o seu nome, assim como ele não é nenhuma das suas imagens. Ele sempre será mais do que seu nome e mais do que suas imagens. (D’Agord et al., 2006, p.120)

\section{O Nome-do-Pai e a Nomeação}

Como visto anteriormente Cruglak (2001) denota que o Nome-do-Pai é o que permite o advento de nomear as coisas. O Nome-do-Pai é o significante “0”, aquele que não conta na cadeia dos significantes, mas que uma vez inscrito age como balizador e possibilitador da inscrição do primeiro significante (S1). O Nome-do-Pai, portanto, é um significante que precisa estar fora da cadeia para que esta possa circular, a circulação dos significantes que permite ao sujeito a nomeação, as identificações.

É importante ressaltar, tal como menciona Porge (1998) que: "O termo Nome-do-Pai não se situa portanto, de chofre, no plano da potência falófora, o que o diferencia do pai de Totem e Tabu que se caracteriza por gozar de todas as mulheres" (p. 27), pois não se trata da carnalidade da paternidade, mas sim de um caráter espiritual, uma forma de sublimação: "o Nome-do-Pai, em sua função significante, faz intervir o recurso estruturante na potência paterna como uma sublimação" (p. 27).

Sua função não está associada ao pai imaginário de Totem e Tabu, o pai gozador, mas sim a uma função simbólica: "É no Nome-do-Pai que devemos reconhecer o suporte da função simbólica que, desde a aurora dos tempos históricos, identifica sua pessoa à figura da lei” (Lacan, 1998, p. 279). O Nome-do-Pai introduz a dimensão da lei simbólica, oferecendo ao gozo pulsional desmedido uma organização.

Devemos nos ater a uma importante diferenciação, explicitada por Porge (1998) ao afirmar que o Nome-do-Pai se assemelha a um nome próprio, e tem algo a ver com o nome próprio do pai, mas não se reduz a ele (p.9). O nomedo-pai é o nome próprio ao pai, nomeado e nomeante (p.9). Vai afirmar também que existem 4 funções associadas ao Nome-do-Pai (Porge, 1998, p.14):

\section{- Procriação \\ - Interdição do incesto \\ - Relação do significante à lei \\ - Função de nomear}

Seguindo esta relação entre nome próprio e Nome-doPai vamos entrar agora numa discussão sobre a questão do nome próprio em Lacan, interrogando a função do nome e a dimensão significante da nomeação. 


\section{A Questão do Nome Próprio em Lacan}

As questões apresentadas por Harari (2001) nos parecem um excelente ponto de partida para nossa discussão sobre o nome próprio. Como o autor coloca:

Se perguntamos, uma vez mais pelo nome próprio, surgem, no mínimo, estas interrogações: de onde "saiu"? Pertence ao "mundo interior" de cada um? Pertence-lhe, claramente? É aquilo que melhor designa o sujeito? É o portador - o porta-voz - de sua singularidade? (Harari, 2001, p.75)

Lacan (2003) já acentuou que "o sujeito é o que se nomeia" (p. 102), essa afirmativa destaca a função nome próprio, o nome como significante que representa o sujeito. Já discutimos anteriormente as identificações imaginária e simbólica, e o modo como através da alienação o sujeito se identifica a um significante unário que passa a representálo no campo do Outro, o significante que o nomeia. O nome próprio, como destacado por Harari (2001) gera uma identificação imaginária, na medida em que sutura, nutre o desconhecimento próprio da constituição do eu (p. 76). A alienação proposta pelo nome próprio comporta um verniz narcísico incessante, derivado do que implica o "reconhecerse" em si mesmo (p.87).

Soler (2009) referindo-se ao nome próprio coloca que: “O patronímico é um nome recebido por meio da genealogia, um nome transmitido, digamos que ele vem automaticamente do Outro" (p.172). A autora lista três importantes características do nome próprio (patronímico):

- Transmitido automaticamente do Outro

- Nas alianças familiares e casamentos

- Diz respeito à língua registrando a genealogia paterna

Por meio do nome próprio se produz um registro, no campo social, da paternidade, da linhagem que antecede o sujeito, à qual ele pertence. Também é importante frisar que nas alianças familiares o nome próprio é transmitido (do marido para a esposa e para os filhos), muito embora hoje encontremos diversas configurações diferentes. Em todo caso o nome exerce uma função identitária e representativa para o sujeito no campo da linguagem.

Seu nome, na mesma medida em que o representa, o apaga, afanisa, pois não diz algo de sua suposta essência. Essa nomeação aliena o sujeito ao desejo do Outro ao mesmo tempo em que o insere no campo do Outro, no campo da linguagem. Paradoxalmente, Somente com o assujeitamento ao desejo do Outro é que o sujeito pode atingir o advento da linguagem, pode ascender ao campo do simbólico. Como afirma Porge (1998) o nome próprio divide o sujeito, pois na tentativa de se agarrar a seu nome como forma de identificação ele se depara inevitavelmente com uma determinação exterior que o ultrapassa. Seu nome veio de seus pais, a tomada de identificação por este meio o confronta com o desejo do Outro.

No entanto, sem este processo de sujeição ao Outro, sem essa "tolice" fortuita, o sujeito fica à mercê da errância significante, fora do campo da linguagem, é o que nos diz Lacan no seminário Les non-dupes errent ${ }^{l}$ sobre a estrutura de linguagem: "É preciso ser tolo, quer dizer, colar, colar, na estrutura" (Lacan, 1974, p.8).

O nome, tal como nos ensina Lacan (2003) é: "uma palavra para designar as coisas particulares como tais, fora de toda descrição" (p.85). Com isso Lacan assevera que o nome tem sentido, mas que inversamente à fala comum, onde interessa a comunicação, o nome produz uma marca por certa diferença sonora (p.88). No mesmo sentido, como afirmado por Harari (2001), a nomenclatura consiste em colocar um selo, um selo no qual figura um nome, apresentando o nome como uma marca colocada pelo Outro, marca do desejo do Outro, pois o nome próprio para Lacan é algo a que o sujeito se identifica pelo modelo da segunda fonte identificatória, uma identificação ao traço unário do Outro, marca distintiva de pura diferença impressa na carne do sujeito pelo significante oferecido pelo Outro.

O autor assevera que o nome próprio é insubstituível, porque, ao faltar, deixa um furo (Harari, 2001, p. 66). "O nome próprio, o intraduzível, o sonorizado, ostenta a propriedade de ser insubstituível; por isso, se não está, ali sim algo falta. Consequentemente, "faz" furo; este se converte em seu reenvio, em sua remissão". No mesmo sentido, Soler (2009) afirma:

Diferente do nome comum cujo referente é geralmente uma classe de coisas, espera-se do patronímico a indexação de uma, e apenas uma, existência independente de qualquer qualidade, a não ser a descendência. Nesse sentido, o patronímico não é um significante, pois tende a designar independentemente do sentido. (Soler, 2009, p.172)

Importante mencionarmos também a função do nome comum, prenome dado ao sujeito em adição ao patronímico. É o prenome que no senso comum é tomado como o nome do sujeito, seu nome de identidade:

O prenome que se acrescenta ao patronímico é completamente diferente: ele não é transmitido automaticamente, mas inscreve uma escolha. Além disso,

1 Seminário, o livro 21, traduzido para o português como "Os não-tolos erram". 
é sempre o estigma do desejo do Outro em relação àquele que acabou de chegar. Em outras palavras, um significado do Outro $[\mathrm{s}(\mathrm{A})]$ que traz consigo o rastro de seus sonhos e expectativas. (Soler, 2009, p.172)

Podemos ver diferenças importantes em relação ao patronímico, e talvez a mais importante delas seja a questão da escolha e do estigma, uma vez que ao contrário do patronímico não há uma transmissão automática, há uma escolha, escolha feita pelo Outro. Estes dois pontos certamente serão retomados mais à frente.

Retomando as interrogações que abrem este tópico, já podemos traçar um "quadro" sobre a noção de nome. De onde saiu? Do campo do Outro, como discutido anteriormente em referência ao processo de alienação (ver 2.4.2). Sendo um significante, entre outros, também o nome "vem" do campo da linguagem, exterior e anterior ao sujeito. O patronímico é transmitido automaticamente pela linhagem (é da ordem do Nome-do-Pai), o prenome é adicionado a ele como uma marca do desejo do Outro.

Pertence ao "mundo interior" de cada um? Pertencelhe, claramente? Sendo um significante ao qual o sujeito se identifica pela via do traço unário é plausível afirmarmos que produz um tipo de efeito identitário, associado à identificação imaginária, a uma pretensa imagem totalitária, uma vez que fracassa em sua tentativa de singularizá-lo: “...o nome próprio é insuficiente para identificar, não consegue levar a cabo seu verdadeiro programa: identificar um, e apenas um, indivíduo" (Soler, 2009, p.172-3). Tanto é que nos utilizamos de diversos outros recursos para tentar suprir esse fracasso, tais como por exemplo:

- Carteira de identidade, que contém os traços do nascimento do sujeito: data, local e funciona como registro.

- Impressões digitais como marca de singularidade do corpo, também os genes no DNA.

- Grafia como traço de singularidade, principalmente no que diz respeito à assinatura (infalsificável).

Todos os exemplos mencionados acima mostram tentativas aplicadas pelas formas de organização social em produzir um tipo de controle da singularidade, registro infalsificável que permita a distinção inequívoca dos indivíduos no laço social.

É aquilo que melhor designa o sujeito? É o portador - o porta-voz - de sua singularidade? Seu efeito é de "denotação", como coloca Harari (2001), o nome denota algo do sujeito, não pode, porém se confundir com a sua singularidade, posto que aparece como um dado narcísico que o "petrifica", afanisando-o no mesmo movimento em que o apresenta. Julgamos necessário fazermos uma retomada daquilo que discutimos até então a respeito da questão do nome.

O nome próprio (patronímico) é transmitido automaticamente pela herança genealógica, é da ordem do Nome-do-Pai, sua transmissão garante ao sujeito seu lugar no campo da linguagem e lhe oferece uma posição no laço social, como descendente de uma linhagem, o nome próprio também é intraduzível. O nome comum (prenome) configura uma escolha, escolha efetuada pelo Outro, é um nome que vem do outro, e não automaticamente, foi selecionado pelo Outro e figura como uma marca de seu desejo no sujeito.

Parece-nos digno de nota acentuar que o nome recorta um objeto (Harari, 2001), a partir da nomeação se produz algo ali onde havia "isso", uma coisa. A nomeação fornece consistência e "identidade" a algo que era pura existência, a exemplo do efeito que o significante opera ao marcar a carne do bebê, sujeito em sua estúpida existência. Sabemos, contudo, que os efeitos de consistência assim como os identitários são da ordem do imaginário, relativos à pretensa imagem total do corpo, imagem narcísica do eu. Sabemos, no entanto, que tanto o nome próprio como o nome comum também são da ordem do simbólico, uma vez que carregam consigo aspectos culturais, relacionados à linguagem e à transmissão de uma linhagem numa determinada cultura.

O nome, na condição de significante entre outros, porta ao mesmo tempo as propriedades de representação e apagamento do sujeito, pois a condição própria para o aparecimento do sujeito é que ele desponta na cadeia significante afanisado, apagado por trás do significante que lhe fornece materialidade.

O nome próprio também tem como característica a intradutibilidade, pois como nos lembra Lacan (2003) não importa em que cultura estejamos, que língua estejamos falando, o nome próprio não possui tradução, ele se mantém sempre o mesmo (p.87). Passamos agora à discussão, tal como proposta por Soler (2009) a respeito de diversas operações de nomeação presentes na cultura.

\section{Nomear e Renomear}

Soler (2009) nos apresenta algumas modalidades de nomeações utilizadas nos mais variados contextos. Nosso intuito aqui é o de visitar essas formas de nomeação discutindo seus mecanismos próprios de operação. A primeira das operações de renomeação apontadas pela autora é a adição de um traço identificador ao nome próprio. Esta operação busca completar o patronímico com um traço que identifique uma singularidade que permita alcançar, sem possibilidade de confusão, o Um da identidade (Hitler, o homem que mais matou Judeus; Alexandre, o grande, etc). Essa renomeação consiste na adição de um qualitativo, algo que informa a respeito dos feitos singulares do nomeado. 
Outra forma de renomeação apresentada pela autora é a imposição de nomes de "indignidade": "Há também os nomes de indignidade impostos, que vêm do Outro, sem que haja consentimento..." (Soler, 2009, p.175). Se a modalidade anterior visa destacar a singularidade do nomeado aqui teremos a imposição de nomes que caem no âmbito das maldições, de um mal-dizer acerca do nomeado. Talvez possamos incluir nesta categoria os apelidos impostos com o intuito de marcar defeitos ou acentuar indignidades do nomeado.

De forma oposta também encontramos as nomeações de propriedades que constituem competências, nomeações que enfatizam os méritos do nomeado: "São nomeações socializadas e socializadoras que inscrevem o ser identificado no laço social"'(Soler, 2009, p.175). Esta forma de renomeação está enfatizada em todas as camadas da atividade social, em toda sorte de atribuição de títulos relativos à conquista de determinada competência (graduações, ascensões sociais e políticas, etc.). Se os nomes de indignidade são impostos e marcam o nomeado como um estigma as nomeações de competência fazem parte das modalidades de se fazer laço com o outro e inserem o nomeado nas matrizes da organização social, como uma identidade relativa a um papel que desempenha na cultura.

Também há a questão do "renome", a palavra que se usa para dizer a celebridade (p.174). Aqui a fama do nomeado o conduz a uma operação específica em que ele "faz-se um nome", uma segunda operação de nomeação, pois como coloca a autora: "O nome de renome consegue aquilo em que o primeiro fracassa, ou seja, indexar juntos uma existência e seus traços de unicidade, enodando o patronímico à singularidade distinta" (Soler, 2009, p.174).

Existem outras modalidades de nomeação presentes em nossa cultura das mais variadas formas. A critério de exemplo, podemos destacar a adição do patronímico do marido no ato do casamento, as mudanças de nome escolhidas quando um indivíduo escolhe fazê-lo e muitas outras. No entanto, julgamos ser impossível avançar mais do que isso diante dos dados que possuímos agora, e deixaremos essas questões em aberto para outro momento.

A operação que deixamos por último é a do renome, de "fazer-se um nome". Optamos por comentá-la no final por que, como referenciado por Soler (2009) e Harari (2001) Lacan propõe essa operação para falar do trabalho de James Joyce em sua elaboração do conceito de sinthome. Soler (2009), comentando o trabalho de Lacan a respeito de Joyce, afirma que renomear-se tem uma função borromeana (p.174), função de enodamento para o sujeito.

Como pudemos ver a questão das identificações está diretamente relacionada à questão das nomeações. É através das identificações que o sujeito se constitui enquanto ser falante e faltante, sujeito do inconsciente, uma vez que é na adição dos elementos vindos do outro - e das marcas deixadas pelo desejo do Outro - que a trama do romance inconsciente do sujeito vai sendo tecida.

As nomeações se configuram como operações de amarração, onde um determinado significante passa a fazer um tipo de ancoragem para o psiquismo. Vimos que em suas mais variadas formas as nomeações de algum modo marcam o sujeito, o inscrevem de uma determinada forma no simbólico. Da mesma forma que as identificações são constantes e sucessivas, se inscrevendo e reinscrevendo, também as operações de nomeação-em suas múltiplas facetas - se apresentam constantemente, não apenas na afirmação de um nome de batismo, mas em todos os momentos em que somos convocados socialmente a dar conta de algo, quando são interpelados pelo Outro e precisamos fazer frente a nosso desejo.

\section{Referências}

Cruglak, C. (2001). Clínica da identificação. Rio de Janeiro: Companhia de Freud.

D'Agord, M. R. L, Binkowski, G. I., \& Chittoni, F. B. (2006). Classes interativas e identificação em psicopatologia. Latin-American Journal of Fundamental Psychopathology, 7(1), 116-130.

David-Ménard, M. (1994). Identificação e hysteria. In M. Mannoni (Org.), As identificações na clínica e na teoria psicanalítica (pp. 69-83). Rio de Janeiro: Relume-Dumará.

Florence, J. (1994). As identificações. In M. Mannoni (Org), As identificações na clínica e na teoria psicanalítica (pp. 115-134). Rio de Janeiro: Relume-Dumará.

Freud, S. (1983a). Recomendações aos médicos que praticam a psicanálise. In J. Strachey (Org.), Obras psicológicas completas de Sigmund Freud (Vol. 10). Rio de Janeiro: Imago. (Originalmente publicado em 1913)

Freud, S. (1983b). Psicologia das massas e análise do eu. In J. Strachey (Org.), Obras psicológicas completas de Sigmund Freud (Vol. 18). Rio de Janeiro: Zahar. (Originalmente publicado em 1921)

Harari, R. (2001). O que acontece no ato analítico? A experiência da psicanálise. Rio de Janeiro: Companhia de Freud.

Lacan, J. (2003). Identificação, O seminário livro 91961 1062 (I. Correia, \& M. Bagno, Trad). Recife: Centro de Estudos Freudianos do Recife. (Versão não oficial) 
Lacan, J. (1974). Os não-tolos erram, Seminário Livro 21. (Versão não oficial)

Lacan, J. (1998). O estádio do espelho. In J. Lacan, Escritos. Rio de Janeiro: Jorge Zahar.

Porge, E. (1998). Os Nomes-do-Pai em Jacques Lacan. Rio de Janeiro: Companhia de Freud.

Safouan, M. (2006). Lacaniana I: Os seminários de Jacques Lacan 1953-1963. Rio de Janeiro: Companhia de Freud. (Versão não autorizada)

Sales, L. S. (2005). Posição do estágio do espelho na teoria lacaniana do imaginário. Revista do departamento de psicologia da UFF, 17(1), 113-127.

Soler, C. (2009). Os nomes da identidade. Trivium: Estudos interdisciplinares psicanálise e cultura, 1(1), 171-177.

Taillandier, G. (1994). Resenha do seminário "A identificação" de J. Lacan. In M. Mannoni, (Org). As identificações na clínica e na teoria psicanalítica. Rio de Janeiro: Relume-Dumará.

Vanier, A (2000). Lacan. Paris: Les belles lettres.

\section{Endereço para correspondência:}

Leonardo Barros de Souza

Endereço: Rua do Jangadeiro, 104 - Mondubim, Fortaleza, Ceará.

E-mail: leoyakushi1@gmail.com 